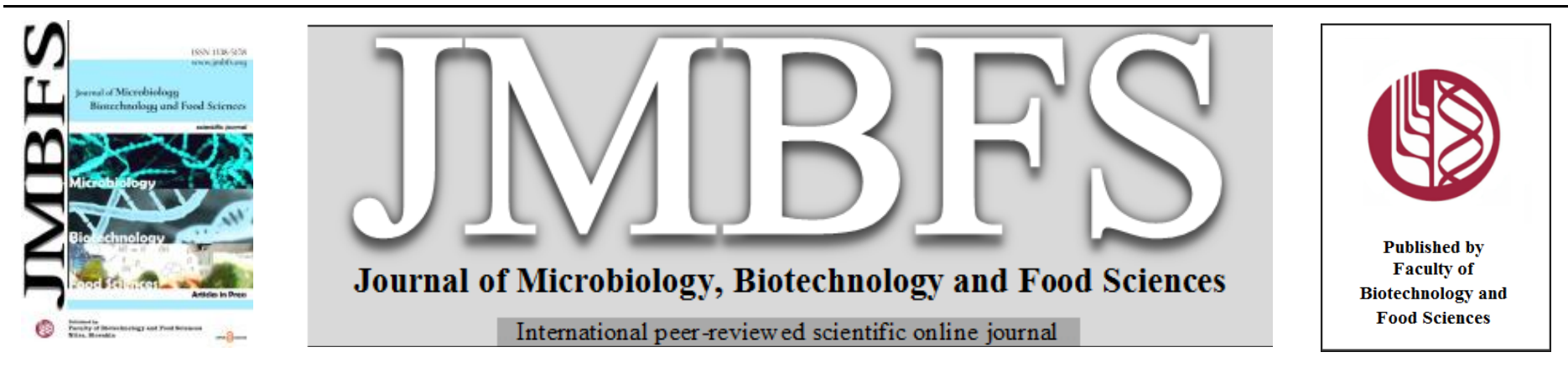

\title{
EFFECT OF TIME AND INCUBATION TEMPERATURE ON ABILITY OF PROBIOTICS FOR REMOVAL OF POLYCYCLIC AROMATIC HYDROCARBON IN PHOSPHATE BUFFER SALINE
}

\author{
Mojtaba Yousefi ${ }^{1}$, Hedayat Hosseini ${ }^{2}{ }^{*}$, Nasim Khorshidian $^{3}$, Hossein Rastegar $^{4}$, Ehsan Shamloo $^{5}$, Anna Abdolshahi ${ }^{1}$
}

Address(es):

${ }^{1}$ Food Safety Research Center (Salt), Semnan University of Medical Sciences, Semnan, Iran.

${ }^{2}$ Department of Food Science and Technology, National Nutrition and Food Technology Research Institute, Faculty of Nutrition Sciences and Food Technology, Shahid Beheshti University of Medical Sciences, Tehran, Iran.

${ }^{3}$ Department of Food Technology Research, Faculty of Nutrition Sciences and Food Technology, National Nutrition and Food Technology Research Institute, Shahid Beheshti University of Medical Sciences, Tehran, Iran.

${ }^{4}$ Food and Drug Laboratory Research Center, Food and Drug Organization, Tehran, Iran.

${ }^{5}$ Department of Food Science and Technology, Neyshabur University of Medical Sciences, Neyshabur, Iran.

*Corresponding author: hedayat@sbmu.ac.ir

https://doi.org/10.55251/jmbfs.1918

ARTICLE INFO

Received 8. 7. 2019

Revised 19. 2. 2022

Accepted 21. 2. 2022

Published 1. 8. 2022

Regular article OPEN $\partial_{\text {ACCESS }}$

\section{ABSTRACT}

The ability of Lactobacillus acidophilus LA-5, Bifidobacterium lactis BB-12, Lactobacillus delbrueckii subsp. bulgaricus PTCC 1737 and Streptococcus thermophilus PTCC 1738 in removing Benzo(a)pyrene (BaP), Benz(a)anthracene (BaA), Chrysene (Chr) and Benzo(b)fluoranthene $(\mathrm{BbF})$ from contaminated aqueous solution with respect to strain types, time and temperature of incubation was studied. The results showed that $\mathrm{BaA}, \mathrm{Chr}, \mathrm{BbF}$ and $\mathrm{BaP}$ could be significantly removed from the phosphate buffer saline by the tested bacteria and this reduction significantly depends on strain types and incubation temperature and time. The reduction of four PAHs varied in the range from $50.94 \%$ to $74.51 \%, 54.48 \%$ to $77.98 \%, 47.35 \%$ to $68.84 \%$, and $61.96 \%$ to $81.22 \%$ for $\mathrm{BaA}$, $\mathrm{Chr}$, $\mathrm{BbF}$ and $\mathrm{BaP}$, respectively. The results illustrated that by increasing time and temperature of incubation, binding ratio increased and the highest binding ratio of four PAHs was achieved by L. acidophilus LA- 5 at $37^{\circ} \mathrm{C}$. Furthermore, the FTIR analysis was performed for identifying the different functional groups that might participate in the binding of PAHs to bacterial cell wall. The FTIR revealed that cell wall has an important role in removal of $\mathrm{BaA}, \mathrm{Chr}, \mathrm{BbF}$ and $\mathrm{BaP}$ from phosphate buffer saline.

Keywords: Adsorption, Cell wall, FTIR, Lactic acid bacteria, Polycyclic aromatic hydrocarbon, Probiotics

\section{INTRODUCTION}

The presence and formation of carcinogenic and toxic compounds in food are one of the most important human concerns in the food industry in recent years. Heavy metals, mycotoxins, nitrosamines, heterocyclic aromatic amines (HCA), acrylamide and polycyclic aromatic hydrocarbons (PAHs) can be named as an example of these carcinogens that have been found in human diets (Khorshidian et al., 2016). Some of these compounds come from the environment, water and contaminated raw materials, and some others are formed during food processing (Zhao et al., 2013). Polycyclic aromatic hydrocarbons (PAHs) are a group of organic compounds that contain at least two fused aromatic rings of carbon. They are environmental pollutants and can enter the food chain through contamination of water, air and soil (Amirdivani et al., 2019; Purcaro et al., 2013; Yousefi, Shemshadi, et al., 2018). Beside of incomplete combustion of fossil fuels, pyrolysis of organic matter and geochemical processes, PAHs can be formed through different food processing methods such as frying, barbecuing, smoking, roasting, baking and drying (Bansal \& Kim, 2015; Naseri et al., 2010; Yousefi, Shemshadi, et al., 2018). Therefore, contamination of various foodstuffs such as smoked food products, meat products, oil and fat with PAHs is inevitable.

Except for occupational and smoker individuals, the most important route of PAHs exposure takes place by dietary intake of food and water (Bansal \& Kim, 2015; Shi et al., 2016). It has been reported that PAHs have toxic, carcinogenic, mutagenic and teratogenic properties and therefore, due to their proven adverse health effect, there is a concern about the presence of PAHs in foods (Mocek $\boldsymbol{\&}$ Ciemniak, 2016). Therefore, different methods are used to significantly reduce contaminants amount to acceptable levels (Dowaidar et al., 2007; Kawashima et al., 2009; Mandal \& Das, 2018; Zeledon-Toruno et al., 2007). Today, attention has been drawn to the use of microorganisms, especially probiotics and lactic acid bacteria, in reducing toxic compounds and contaminants (Eddine et al., 2018; Halttunen et al., 2008; Hamad et al., 2017; Hathout \& Aly, 2014; Yousefi, Shariatifar, et al., 2018; Zou et al., 2015). Lactic acid bacteria (LAB), particularly, probiotics bring beneficial effects to the host when consumed in adequate quantity. Various health benefits attributed to the LAB and probiotics, among which antimutagenic properties have been considered by researchers. LABs and probiotics may prevent cancer through various mechanisms such as increasing activity of antioxidative enzymes, conversion of procarcinogens and carcinogens into less toxic metabolites, lowering the intestinal $\mathrm{pH}$ and binding the mutagens through the cell surface and peptidoglycans (Gupta \& Sharma, 2017; Ryu \& Chang, 2013; Tumbarski et al., 2018; Yousefi et al., 2017; Yousefi et al., 2021) It seems that the binding of toxin to cell wall is one of the most important mechanisms that participates in removing toxin and carcinogens and many studies investigated the ability of LABs and probiotics in removing various toxins However, there are few studies in removing PAHs by LABs and probiotics. Therefore, this study is focused on the effect of time and temperature of incubation on the PAHs adsorption of LABs and probiotics as well as determining interaction types.

\section{MATERIAL AND METHODS}

\section{Bacterial strains and media}

Strains of Lactobacillus acidophilus LA-5 and Bifidobacterium lactis BB-12 were obtained from Chr. Hansen (Denmark). Lactobacillus delbrueckii subsp. bulgaricus PTCC 1737 and Streptococcus thermophilus PTCC 1738 were purchased from the Iranian Research Organization for Science and Technology (IROST). The strains were kept at $-18^{\circ} \mathrm{C}$ until they used. De Man-Rogosa-Sharpe (MRS) media, all chemical and solvents were provided from Merck (Darmstadt, Germany).

\section{Bacterial growth condition}

All strains except for B. lactis BB-12 were activated in MRS broth for $24 \mathrm{~h}$ at $37^{\circ} \mathrm{C}$. $B$. lactis was cultured in the same medium plus $0.05 \%$ of L-cysteine at $37^{\circ} \mathrm{C}$ for 24 $\mathrm{h}$ in an anaerobic incubator. Then, $1 \mathrm{ml}$ of 24 -hold culture was added to $100 \mathrm{~mL}$ fresh MRS broth and incubated at $37^{\circ} \mathrm{C}$ for about $18-20 \mathrm{~h}$ until bacterial population reached to $1 \times 10^{10} \mathrm{CFU} / \mathrm{mL}$. Bacterial count was determined by plate counting method (Niderkorn et al., 2006). After that, the bacterial pellet were obtained from MRS medium by centrifugation at $5000 \mathrm{~g}$ for $15 \mathrm{~min}$ at $4^{\circ} \mathrm{C}$ (Hettich, Tuttlingen, Germany). The obtained cells were washed with phosphate buffer saline (PBS, pH $7.2,0.85 \% \mathrm{NaCl}$ ) and finally used in binding assays. 


\section{Preparation of BaP, BaA, Chr and BbF standard solutions}

Four PAHs namely Benzo(a)pyrene (BaP), Benz(a)anthracene (BaA), Chrysene (Chr) and Benzo(b)fluoranthene $(\mathrm{BbF})$ which obtained from Sigma-Aldrich (Steinheim, Germany) (purity of $\geq 99.5 \%$ ) were dissolved in dichloromethane to obtain a stock solution with concentration of $5 \mathrm{mg} / \mathrm{mL}$ of each PAHs. The work solution $\mathrm{I}(0.5 \mathrm{mg} / \mathrm{mL})$ was prepared by adding $1 \mathrm{~mL}$ of stock solution into $9 \mathrm{~mL}$ methanol. After that, working solution II with concentration of $10 \mu \mathrm{g} / \mathrm{mL}$ of each PAHs was obtained by dilution of working solution I with phosphate buffer saline $(\mathrm{pH}=5)$. Based on the previous study, it was found that the beast binding reaction was carried out in pH 5 (Yousefi et al., 2019).

Effect of temperature and time of incubation on PAH-binding ability of bacteria

Each bacterial pellet with specific concentration $\left(1 \times 10^{10} \mathrm{CFU} / \mathrm{mL}\right)$ that harvested by centrifuging at $5000 \mathrm{~g}$ for $15 \mathrm{~min}$ at $4^{\circ} \mathrm{C}$ was washed twice with phosphate buffer saline and suspended into $1 \mathrm{~mL}$ working solution II containing $10 \mu \mathrm{g} / \mathrm{mL}$ of $\mathrm{BaP}, \mathrm{BaA}, \mathrm{Chr}$ and $\mathrm{BbF}$ with $\mathrm{pH}$ 5. The $\mathrm{pH}$ of the working solution II was adjusted to 5.0 with $1.0 \mathrm{~mol} / 1 \mathrm{HCl}$. The mixture transferred into an Eppendorf vial, shaken thoroughly and finally placed in shaking incubator $(100 \mathrm{rpm})$ at 4,25 and $37^{\circ} \mathrm{C}$ for $10 \mathrm{~h}$ to evaluate the effect of temperature on the PAHs adsorption of tested bacteria Moreover, in order to study the effect of incubation time, the mixture of bacteria pellet and PAHs were placed in shaking incubator for $24 \mathrm{~h}$ at the best temperature point that have been obtained in the previous step. After incubation, bacterial suspensions were centrifuged and the amount of free PAHs in cell-free supernatant was analyzed using GC-MS. PBS with PAHs and PBS with bacterial strains were used as positive and negative controls, respectively.

\section{Quantitation of unbound PAHs by GC-MS}

Unbound $\mathrm{BaP}, \mathrm{BaA}, \mathrm{Chr}$ and $\mathrm{BbF}$ in cell free supernatants was determined by GC/MS. Prior to GC analysis, $1 \mathrm{~mL}$ of cyclohexane was added to the $1 \mathrm{~mL}$ of cell free supernatants and thoroughly mixed for about $1 \mathrm{~min}$ and centrifuged at 10000 $\mathrm{g}$ for $10 \mathrm{~min}$. Then $1 \mu \mathrm{L}$ of the upper phase was directly injected to GC/MS for determining the amount of free $\mathrm{BaP}, \mathrm{BaA}, \mathrm{Chr}$ and $\mathrm{BbF}$. Agilent Technologies 7890A GC system with triple-axis detector (HP-5 MS capillary column, 30m $\times$ $250 \mu \mathrm{m}$ ID, $0.25 \mu \mathrm{m}$ film thickness) coupled with a 5975C inert MSD network mass selective detector was used to separate and quantify $\mathrm{BaP}, \mathrm{BaA}, \mathrm{Chr}$ and $\mathrm{BbF}$. Helium was used as carrier gas at a constant flow rate of $1 \mathrm{~mL} / \mathrm{min}$. The injection port temperature was $290^{\circ} \mathrm{C}$ and almost $1 \mu \mathrm{m}$ of the sample was injected into a split mode for analysis (split ratio 1:25). The column temperature was held at $220^{\circ} \mathrm{C}$ for 5 minutes. Then increased to $290^{\circ} \mathrm{C}$ at a rate of $3^{\circ} \mathrm{C} / \mathrm{min}$ and held for 5 min. selected ion monitoring (SIM) mode was used for the quantitative and qualitative analysis of 4 PAHs. The percentage of bounded PAHs was calculated using the following equation:

Binding ratio $(\%)=\left[1-\left(\frac{\text { Peak area of each } P \text { AHs in sample }}{\text { Peak area of each PAHs in positive control }}\right)\right] \times 100$

\section{Fourier Transform Infra-Red (FTIR) spectroscopic analysis}

FTIR analysis of bacterial pellet with and without PAHs were carried out using FTIR spectrophotometer (Fourier transform-infrared spectrometer, PerkinElmer Spectrum RX I, Waltham, MA, USA). Two strains that had the highest binding ability were selected for FTIR analysis. The sample pellets were prepared by mixing bacterial pellet with $\mathrm{KBr}$ (potassium bromide) and analyzed with a spectrophotometer at room temperature in the range of $4000-400 \mathrm{~cm}^{-1}$ at a resolution of $4 \mathrm{~cm}^{-1}$.

\section{Statistical Analysis}

All experiments and analysis were carried out in triplicate and the date was expressed as means \pm standard deviation (SD). One-way ANOVA and Tukey's test using the SPSS 21.0 software package program (SPSS Inc., Chicago, IL) were utilized for the statistical evaluation of data. Values of $\mathrm{P}<0.05$ were considered as significant.

\section{RESULT AND DISCUSSION}

\section{Effect of incubation temperature on binding ability}

The results of the PAHs adsorption to the tested bacteria at different temperatures $\left(4,25,37^{\circ} \mathrm{C}\right)$ are shown in Table 1 . As shown in Table 1 , the tested bacteria can reduce $\mathrm{BaA}, \mathrm{Chr}, \mathrm{BbF}$ and $\mathrm{BaP}$ in vitro and this reduction depends on strain types and incubation temperatures. The results showed that reduction of four PAHs varied in the range from $50.94 \%$ to $74.51 \%, 54.48 \%$ to $77.98 \%, 47.35 \%$ to $68.84 \%$, and $61.96 \%$ to $81.22 \%$ for $\mathrm{BaA}, \mathrm{Chr}, \mathrm{BbF}$ and $\mathrm{BaP}$, respectively (Table 1). As seen in Table 1, in the all tested bacteria, binding ratio increased when temperature of incubation increased and the highest binding ratio of four PAHs was achieved by L. acidophilus LA-5 at $37^{\circ} \mathrm{C}$. Because of the fact that the reduction of various toxins by probiotics is carried out through physical interactions with cell wall, this phenomenon can therefore be influenced by various factors such as incubation temperature (Khorshidian et al., 2016; Zhu et al., 2017). The result of this study is similar to the results of Zhao et al. (2013) that evaluated the effect of incubation temperature on benzo (a) pyren adsorption of probiotics and they found that by increasing temperature from 4 to 40 , benzo (a) pyren binding ability of $L$. plantarum CICC 22135 and L. pentosus CICC 23163 significantly increased (Zhao et al., 2013). It has been reported by Hatab et al. (2012a) that removal of patulin by $\mathrm{LAB}$ was dependent on temperature and the highest reduction was occurred at $37^{\circ} \mathrm{C}$. Furthermore, they found that there were significant differences in patulin binding ratio either at $25^{\circ} \mathrm{C}$ or $37^{\circ} \mathrm{C}$ than at $4{ }^{\circ} \mathrm{C}$ (Hatab et al., 2012a) Similarly, Zhu et al. (2017) found that bisphenol A removal from PBS is temperature-dependent and the optimal temperatures for the removal of bisphenol A from the PBS solution were at 37 and $30^{\circ} \mathrm{C}$ (Zhu et al., 2017). Moreover, Bovo et al. (2013) reported that L. bulgaricus had greater ability to remove AFM1 at $37^{\circ} \mathrm{C}$ in comparison with $4^{\circ} \mathrm{C}$ (Bovo et al., 2013). According to the Table 1 , it could be understood the all tested bacteria showed the highest ability in removing $\mathrm{BaP}$, while the lowest adsorption was observed for $\mathrm{BbF}$, indicating that this even is totally dependent on types of toxin and strains.

\section{Effect of incubation time on binding ability}

Based on the data presented in Table 2, it is observed that the binding ability is also dependent on time of incubation and by increasing incubation time the amount of free $\mathrm{BaA}, \mathrm{Chr}, \mathrm{BbF}$ and $\mathrm{BaP}$ decreased. The highest binding ratio for $\mathrm{BaA}$ (81.52\%), Chr $(80.14 \%) \mathrm{BbF}(73.82 \%)$ and $\mathrm{BaP}(88.45 \%)$ were obtained by $L$ acidophilus LA-5 after $24 \mathrm{~h}$ incubation.

$\underline{\text { Table } 1 \text { Effect of incubation temperature on binding ability }}$

\begin{tabular}{|c|c|c|c|c|c|}
\hline \multirow[t]{2}{*}{ Bacterial strains } & \multirow{2}{*}{ Temperature $\left({ }^{\circ} \mathrm{C}\right)$} & \multicolumn{4}{|c|}{ Percentage of binding (\%) } \\
\hline & & $\mathbf{B a A}$ & $\mathrm{Chr}$ & BbF & BaP \\
\hline \multirow[t]{3}{*}{ Bifidobacterium lactis $\mathrm{BB}-12$} & 4 & $50.94 \pm 1.13^{\mathrm{gC}}$ & $54.48 \pm 1.51^{\mathrm{fB}}$ & $47.35 \pm 0.70^{\mathrm{gC}}$ & $61.96 \pm 1.36^{\mathrm{fA}}$ \\
\hline & 25 & $56.70 \pm 3.30^{\mathrm{efg}}$ & $61.58 \pm 1.23^{\mathrm{deAB}}$ & $51.08 \pm 0.94^{\mathrm{fg}}$ & $65.58 \pm 0.81^{\mathrm{efA}}$ \\
\hline & 37 & $60.54 \pm 2.03^{\mathrm{cdeC}}$ & $64.95 \pm 1.94^{\mathrm{cdB}}$ & $57.23 \pm 1.16^{\mathrm{deCD}}$ & $70.38 \pm 2.48^{\mathrm{cdeA}}$ \\
\hline \multirow[t]{3}{*}{ Lactobacillus acidophilus LA-5 } & 4 & $64.15 \pm 0.96^{\mathrm{bcC}}$ & $67.48 \pm 1.86^{\mathrm{cAB}}$ & $61.42 \pm 1.54^{\mathrm{bcdCD}}$ & $69.87 \pm 1.663^{\text {cdeA }}$ \\
\hline & 25 & $67.15 \pm 2.77^{\mathrm{bC}}$ & $72.91 \pm 1.59^{\mathrm{bB}}$ & $65.04 \pm 1.82^{\mathrm{abCD}}$ & $76.49 \pm 3.05^{\mathrm{abA}}$ \\
\hline & 37 & $74.51 \pm 2.87^{\mathrm{aB}}$ & $77.98 \pm 1.65^{\mathrm{aAB}}$ & $68.84 \pm 1.47^{\mathrm{aC}}$ & $81.22 \pm 2.37^{\mathrm{aA}}$ \\
\hline Lactobacillus bulgaricus PTCC & 4 & $57.69 \pm 1.71^{\mathrm{deB}}$ & $57.01 \pm 1.28^{\mathrm{fB}}$ & $52.04 \pm 1.07^{\mathrm{fC}}$ & $68.20 \pm 0.85^{\mathrm{deA}}$ \\
\hline \multirow[t]{2}{*}{1737} & 25 & $64.54 \pm 1.31^{\mathrm{bcB}}$ & $61.54 \pm 1.68^{\mathrm{deBC}}$ & $57.97 \pm 1.65^{\mathrm{deCD}}$ & $73.11 \pm 2.06^{\text {bcdA }}$ \\
\hline & 37 & $67.32 \pm 2.11^{\mathrm{bBC}}$ & $67.54 \pm 0.81^{\mathrm{cBC}}$ & $63.78 \pm 0.66^{\mathrm{bcC}}$ & $76.12 \pm 0.93^{\mathrm{abA}}$ \\
\hline Streptococcus thermophilus & 4 & $51.45 \pm 2.09^{\mathrm{fg}}$ & $58.05 \pm 1.23^{\mathrm{efB}}$ & $53.97 \pm 1.58^{\mathrm{efCB}}$ & $65.28 \pm 1.19^{\mathrm{efA}}$ \\
\hline \multirow[t]{2}{*}{ PTCC 1738} & 25 & $57.29 \pm 0.87^{\mathrm{efC}}$ & $65.24 \pm 24^{\mathrm{cdA}}$ & $59.78 \pm 2.46^{\mathrm{cdBC}}$ & $69.63 \pm 2.55^{\text {cdeA }}$ \\
\hline & 37 & $63.48 \pm 1.17^{\mathrm{bcdC}}$ & $67.55 \pm 1.38^{\mathrm{cB}}$ & $64.18 \pm 1.19^{\mathrm{bC}}$ & $75.04 \pm 2.19^{\mathrm{bcA}}$ \\
\hline
\end{tabular}

The phosphate buffer solution (pH: 5) contained $1 \times 10^{10} \mathrm{CFU} / \mathrm{mL}$ and $10 \mu \mathrm{g} / \mathrm{mL}$ of each PAHs incubated for $10 \mathrm{~h}$

Values expressed as mean \pm standard deviation for triplicate samples

In each column, different small letters represent statistical difference $(\mathrm{P} \leq 0.05)$

In each row, different capital letters represent statistical difference ( $\mathrm{P} \leq 0.05)$ 
The results also revealed that the lowest ability of bacteria in removing PAHs over $24 \mathrm{~h}$ incubation at $37^{\circ} \mathrm{C}$ was related to B. lactis BB-12. Moreover, nearly in the most trials there were no significant differences among $L$. delbrueckii subsp bulgaricus PTCC 1737 and S. thermophilus PTCC 1738 in reducing PAHs during incubation at $37^{\circ} \mathrm{C}$ for $24 \mathrm{~h}$. It has been reported by zhao et al. (2013) that BaP binding ratio was reached to the maximum amount after $24 \mathrm{~h}$ incubation at $37^{\circ} \mathrm{C}$ and the extra time (24h) has no more effect on binding ratio (Zhao et al., 2013).
On the other hand Zhu et al. (2017) revealed that the highest level of bisphenol A was obtained after $15 \mathrm{~min}$ of incubation time (Zhu et al., 2017). Moreover, Serrano-Niño et al. (2015) pointed out that binding of acrylamide and AFB1 by Lactobacillus strains was relevant to incubation time. They also reported that the amount of free mycotoxin considerably increased when the incubation time enhanced to 4 and 12 h (Serrano-Niño et al., 2015).

Table 2 Effect of incubation time on binding ability

\begin{tabular}{|c|c|c|c|c|c|}
\hline \multirow{2}{*}{ Bacterial strains } & \multirow{2}{*}{ Incubation time $(h)$} & \multicolumn{4}{|c|}{ Percentage of binding $(\%)$} \\
\hline & & $\mathbf{B a A}$ & Chr & $\mathbf{B b F}$ & BaP \\
\hline \multirow{4}{*}{ Bifidobacterium lactis BB-12 } & 4 & $48.21 \pm 0.21^{\mathrm{aB}}$ & $54.19 \pm 0.17^{\mathrm{aC}}$ & $46.58 \pm 0.52^{\mathrm{aA}}$ & $58.40 \pm 0.30^{\mathrm{aD}}$ \\
\hline & 8 & $59.26 \pm 0.18^{\mathrm{cB}}$ & $65.69 \pm 0.22^{\mathrm{bkC}}$ & $53.55 \pm 0.48^{\mathrm{cA}}$ & $66.94 \pm 0.92^{\mathrm{dC}}$ \\
\hline & 16 & $64.12 \pm 0.12^{\mathrm{eB}}$ & $72.44 \pm 0.32^{\mathrm{edC}}$ & $57.40 \pm 0.23^{\mathrm{dA}}$ & $73.20 \pm 0.23^{\mathrm{fC}}$ \\
\hline & 24 & $66.25 \pm 0.22^{\mathrm{fB}}$ & $73.62 \pm 0.45^{\mathrm{eC}}$ & $56.09 \pm 0.93^{\mathrm{cdA}}$ & $74.38 \pm 0.54^{\mathrm{fC}}$ \\
\hline \multirow{4}{*}{ Lactobacillus acidophilus LA-5 } & 4 & $61.58 \pm 0.52^{\mathrm{dB}}$ & $64.38 \pm 0.31^{\mathrm{bC}}$ & $59.58 \pm 0.40^{\mathrm{eA}}$ & $70.57 \pm 0.39^{\mathrm{eD}}$ \\
\hline & 8 & $72.37 \pm 0.33^{\mathrm{hB}}$ & $73.37 \pm 0.45^{\mathrm{eB}}$ & $68.58 \pm 0.52^{\mathrm{iA}}$ & $78.33 \pm 0.81^{\mathrm{gC}}$ \\
\hline & 16 & $75.87 \pm 1.37^{\mathrm{iA}}$ & $78.87 \pm 0.37^{\mathrm{fB}}$ & $74.73 \pm 0.25^{\mathrm{jA}}$ & $85.96 \pm 0.30^{\mathrm{iC}}$ \\
\hline & 24 & $81.52 \pm 0.50^{\mathrm{jB}}$ & $80.14 \pm 0.80^{\mathrm{fB}}$ & $73.82 \pm 0.74^{\mathrm{jA}}$ & $88.45 \pm 0.51^{\mathrm{kC}}$ \\
\hline \multirow{4}{*}{ Lactobacillus bulgaricus PTCC 1737} & 4 & $55.43 \pm 0.62^{\mathrm{bB}}$ & $54.86 \pm 0.35^{\mathrm{aB}}$ & $51.40 \pm 0.37^{\mathrm{bA}}$ & $63.59 \pm 0.15^{\mathrm{cC}}$ \\
\hline & 8 & $66.12 \pm 0.83^{\mathrm{fB}}$ & $67.20 \pm 2.05^{\mathrm{cB}}$ & $62.29 \pm 0.26^{\mathrm{fA}}$ & $73.23 \pm 0.23^{\mathrm{fC}}$ \\
\hline & 16 & $72.33 \pm 0.12^{\mathrm{hB}}$ & $71.19 \pm 0.17^{\mathrm{dB}}$ & $66.24 \pm 0.24^{\mathrm{hA}}$ & $80.24 \pm 0.15^{\mathrm{iC}}$ \\
\hline & 24 & $73.29 \pm 0.25^{\mathrm{hC}}$ & $65.25 \pm 0.66^{\mathrm{bA}}$ & $68.26 \pm 1.41^{\mathrm{iB}}$ & $83.58 \pm 0.52^{\mathrm{hD}}$ \\
\hline \multirow{4}{*}{$\begin{array}{l}\text { Streptococcus thermophilus } \\
\text { PTCC } 1738\end{array}$} & 4 & $55.12 \pm 0.97^{\mathrm{bA}}$ & $55.26 \pm 0.23^{\mathrm{aA}}$ & $55.13 \pm 0.12^{\mathrm{cA}}$ & $60.29 \pm 0.26^{\mathrm{bB}}$ \\
\hline & 8 & $63.43 \pm 0.62^{\mathrm{eA}}$ & $65.32 \pm 0.38^{\mathrm{bcB}}$ & $64.23 \pm 0.11^{\mathrm{gAB}}$ & $69.64 \pm 0.36^{\mathrm{eC}}$ \\
\hline & 16 & $66.87 \pm 0.18^{\mathrm{fA}}$ & $68.00 \pm 1.00^{\mathrm{cA}}$ & $68.49 \pm 0.50^{\mathrm{iA}}$ & $73.21 \pm 0.24^{\mathrm{fC}}$ \\
\hline & 24 & $70.22 \pm 0.23^{\mathrm{gA}}$ & $74.69 \pm 0.63^{\mathrm{eB}}$ & $69.71 \pm 0.22^{\mathrm{iA}}$ & $73.27 \pm 0.33^{\mathrm{fB}}$ \\
\hline
\end{tabular}

The phosphate buffer solution (pH: 5) contained $1 \times 10^{10} \mathrm{CFU} / \mathrm{mL}$ and $10 \mu \mathrm{g} / \mathrm{mL}$ of each PAHs incubated at $37^{\circ} \mathrm{C}$

Values represented as mean \pm standard deviation for triplicate samples

In each column, different small letters represent statistical difference $(\mathrm{P} \leq 0.05)$

In each row, different capital letters represent statistical difference $(\mathrm{P} \leq 0.05)$

\section{FTIR analyses}

FTIR spectra were an important tool for identifying the different functional groups that might participate in the binding of various components to bacterial cell wal (Hatab et al., 2012b). FTIR bands and detailed wavenumber of L. acidophilus and L. bulgaricus before and after PAHs uptake are shown in Table 3. Furthermore, The FTIR spectrum of PAHs - bacteria complex and bacteria without PAHs in the wavenumber range of 400 to $4000 \mathrm{~cm}^{-1}$ are illustrated in Figure 1. Although the FTIR spectra of PAHs - bacteria complex had some changes in comparison with the unexposed bacterial pellet, however, the shapes are almost the same for each strain (exposed and unexposed). The FTIR analysis showed that the wavenumbers 2965 and $1498 \mathrm{~cm}^{-1}$ resulting from the $\mathrm{C}-\mathrm{H}$ stretching mode proposing the presence of aliphatic chain. The peak at 3420, 1637 and 1550 could be attributed to the $\mathrm{O}-\mathrm{H} / \mathrm{N}-\mathrm{H}$ stretching, amide I and amide II, indicating the presence of peptide bonds. Furthermore the wavenumber of 1070 is related to polysaccharides $(\mathrm{C}-\mathrm{O})$
(Guo et al., 2012; S Hatab et al., 2012b). The peak at $960-1150 \mathrm{~cm}^{-1}$ could be ascribed to the asymmetric and symmetric stretching of $\mathrm{PO} 2$ - and $\mathrm{P}(\mathrm{OH}) 2$ in phosphate; vibrations of $\mathrm{C}-\mathrm{OH}$ and $\mathrm{C}-\mathrm{C}$ bonds in polysaccharides and alcohol (Jiang et al., 2004). As it can be seen in Figure 1, by addition of PAHs in bacteria, the $\mathrm{C}-\mathrm{H}$ stretching band and $\mathrm{C}-\mathrm{O}$ polysaccharides band has changed to upper wavenumber. Furthermore, for L. acidophilus LA-5+ PAHs, the intensity of the peak at 1637 has been increased when compared to L. acidophilus LA-5. According to the FTIR spectra, it can be understood that changed absorption bands at 3440,3420 and 2990 relating to $\mathrm{O}-\mathrm{H}$ stretching, $\mathrm{N}-\mathrm{H}$ of the amine groups and $\mathrm{C}-\mathrm{H}$ stretching might be the functional groups that participated in binding of PAHs to bacterial cell wall. Furthermore, for the PAHs exposed bacteria in comparison to unexposed bacteria, the absence of peak at 1564 and 1548 (N-H amide II) might justify the binding of PAHs to the bacterial cell wall.

Table 3 FTIR bands observed for bacterial strains before and after PAHs exposing

\begin{tabular}{|c|c|c|c|c|}
\hline \multirow{2}{*}{ Functional groups } & \multicolumn{4}{|c|}{ Wavenumber (cm1) } \\
\hline & L. acidophilus LA-5+PAHs & L. acidophilus LA-5 & L. bulgaricus PTCC $1737+$ PAHs & L. bulgaricus PTCC 1737 \\
\hline O-H stretching & 3445.14 & 3454.24 & 3498.50 & 3464.23 \\
\hline $\mathrm{N}-\mathrm{H}$ amines & 3419.74 & 3422.43 & 3417 & 3415 \\
\hline $\mathrm{C}-\mathrm{H}$ stretching & 2995.45 & 2969.20 & 2994.22 & 2969.5 \\
\hline $\mathrm{C}=\mathrm{O}$ amide $\mathrm{I}$ & 1637.59 & 1637.44 & 1632.35 & 1635.65 \\
\hline $\mathrm{N}-\mathrm{H}$ amide II & $-{ }^{\mathrm{a}}$ & 1564.3 & $-{ }^{\mathrm{a}}$ & 1548.50 \\
\hline $\mathrm{CH} 2$ bending & 1498 & 1499 & 1485.93 & 1493.60 \\
\hline $\mathrm{C}-\mathrm{O}$ polysaccharides & 1076.50 & 1061.50 & 1077.50 & 1061.26 \\
\hline $\mathrm{PO}_{2}$ & 987.43 & 963.50 & 959.60 & 979.84 \\
\hline
\end{tabular}

\footnotetext{
${ }^{\mathrm{a}}$ Band not observed.
} 


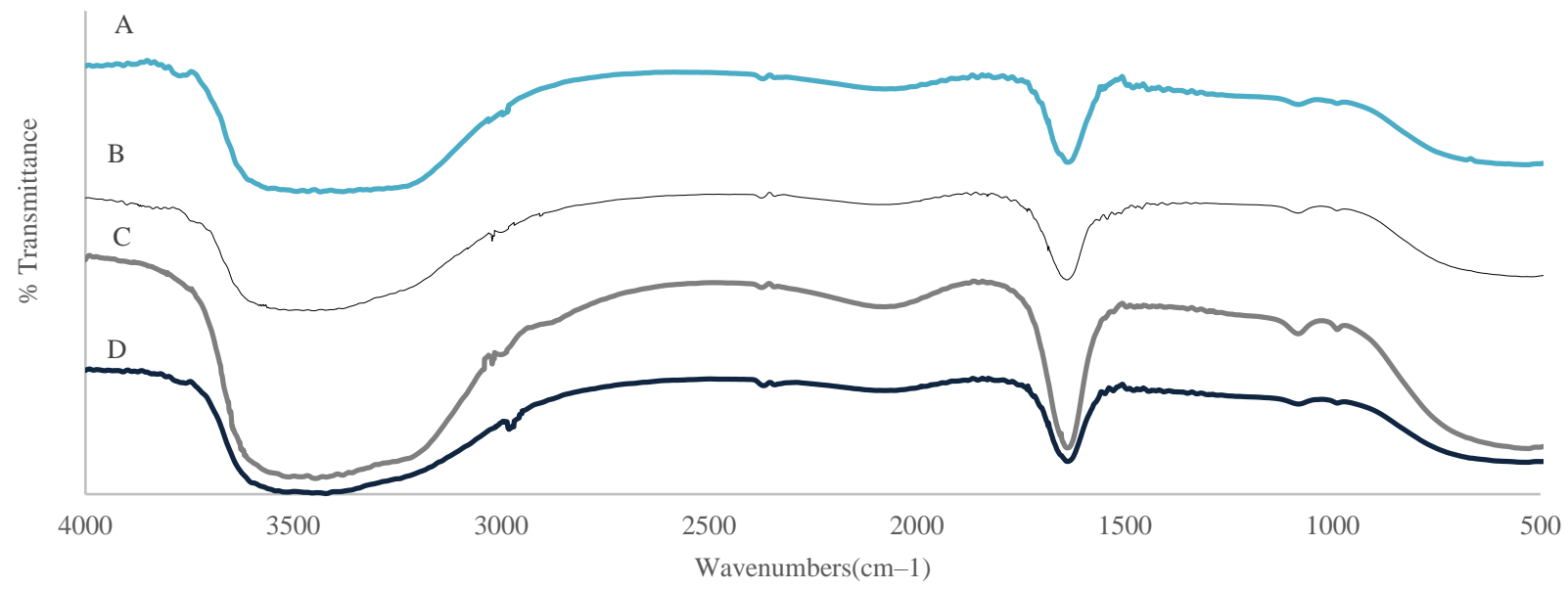

Figure 1 FTIR spectrum of L. bulgaricus PTCC 1737 (A: after PAHs uptake, B: before PAHs uptake) and Lactobacillus acidophilus LA-5 (C: after PAHs uptake, D: before PAHs uptake)

\section{CONCLUSION}

This study demonstrated that remove of $\mathrm{BaA}, \mathrm{Chr}, \mathrm{BbF}$ and $\mathrm{BaP}$ from phosphate buffer saline was carried out by the tested bacteria. The FTIR analysis showed that bacterial cell wall plays an important role in removal of $\mathrm{BaA}, \mathrm{Chr}, \mathrm{BbF}$ and $\mathrm{BaP}$ liquid medium. Therefore, as seen in this study, this reduction significantly affected by strains of bacteria, type of toxin, time and temperature of incubation. The highest and the lowest removal were related to $\mathrm{BaP}$ and $\mathrm{BbF}$, respectively, indicating that this event is toxin-specific. The findings of this study showed that the binding capacity of bacteria increased when time and temperature of incubation increased and the highest binding ratio of four PAHs was achieved by $L$ acidophilus LA-5 at $37{ }^{\circ} \mathrm{C}$. Generally it could be concluded that PAH-binding ability of LABs and probiotics might be considered as a new strategies for decontamination of PAHs from foods.

Conflict of interest: The authors declare there are no conflicts of interest.

\section{REFERENCES}

Amirdivani, S., Khorshidian, N., Ghobadi Dana, M., Mohammadi, R. Mortazavian, A. M., Quiterio De Souza, S. L., Barbosa Rocha, H., \& Raices, R. (2019). Polycyclic aromatic hydrocarbons in milk and dairy products. International Journal of Dairy Technology, 72(1), 120-131. http://dx.doi.org/10.1111/1471-0307.12567

Bansal, V., \& Kim, K. H. (2015). Review of PAH contamination in food products and their health hazards. Environment International, 84, 26-38. http://dx.doi.org/10.1016/j.envint.2015.06.016

Bovo, F., Corassin, C. H., Rosim, R. E., \& De Oliveira, C. A. (2013). Efficiency of lactic acid bacteria strains for decontamination of aflatoxin M1 in phosphate buffer saline solution and in skimmed milk. Food and Bioprocess Technology, 6(8), 2230-2234. http://dx.doi.org/10.1007/s11947-011-0770-9

Dowaidar, A., El-Shahawi, M., \& Ashour, I. (2007). Adsorption of polycyclic aromatic hydrocarbons onto activated carbon from non-aqueous media: 1 . The influence of the organic solvent polarity. Separation Science and Technology, 42(16), 3609-3622. https://doi.org/10.1080/01496390701626537

Eddine, S. D., Yasmine, S., Fatima, G., Amina, Z., Battache, G., \& Mebrouk, K. (2018). Antifungal and antibacterial activity of some lactobacilli isolated from camel's milk biotope in the south of Algeria. Journal of Microbiology, Biotechnology and Food Sciences, 8(3), 871-877. http://dx.doi.org/10.15414/JMBFS.2018-19.8.3.871-877

Guo, C., Yuan, Y., Yue, T., Hatab, S., \& Wang, Z. (2012). Binding mechanism of patulin to heat-treated yeast cell. Letters in Applied Microbiology, 55(6), 453-459. https://doi.org/10.1111/j.1472-765x.2012.03314.x

Gupta, A., \& Sharma, N. (2017). In vitro characterization of lactic acid bacteria isolated from Lasoda bari-A rare fermented food of Himachal Pradesh-India for potential probiotic attributes. Journal of Microbiology, Biotechnology and Food Sciences, 6(6), 1323-1328. http://dx.doi.org/10.15414/jmbfs.2017.6.6.1323-1328 Halttunen, T., Collado, M., El-Nezami, H., Meriluoto, J., \& Salminen, S. (2008) Combining strains of lactic acid bacteria may reduce their toxin and heavy metal removal efficiency from aqueous solution. Letters in Applied Microbiology, 46(2), 160-165. http://dx.doi.org/10.1111/j.1472-765X.2007.02276.x.

Hamad, G. M., Zahran, E., \& Hafez, E. E. (2017). The efficacy of bacterial and yeasts strains and their combination to bind aflatoxin B1 and B2 in artificially contaminated infants food. Journal of Food Safety, 37(4), e12365. http://dx.doi.org/10.1111/jfs.12365

Hatab, S., Yue, T., \& Mohamad, O. (2012a). Reduction of patulin in aqueous solution by lactic acid bacteria. Journal of food science, 77(4), 238-241. http://dx.doi.org/10.1111/j.1750-3841.2011.02615.x

Hatab, S., Yue, T., \& Mohamad, O. (2012b). Removal of patulin from apple juice using inactivated lactic acid bacteria. Journal of Applied Microbiology, 112(5), 892-899. http://dx.doi.org/10.1111/j.1365-2672.2012.05279.x

Hathout, A. S., \& Aly, S. E. (2014). Biological detoxification of mycotoxins: review. Annals of microbiology, 64(3), 905-919. https://doi.org/10.1007/s13213 014-0899-7

Jiang, W., Saxena, A., Song, B., Ward, B. B., Beveridge, T. J., \& Myneni, S. C. (2004). Elucidation of functional groups on gram-positive and gram-negative bacterial surfaces using infrared spectroscopy. Langmuir, 20(26), 11433-11442. http://dx.doi.org/10.1021/la049043

Kawashima, A., Watanabe, S., Iwakiri, R., \& Honda, K. (2009). Removal of dioxins and dioxin-like PCBs from fish oil by countercurrent supercritical $\mathrm{CO}_{2}$ extraction and activated carbon treatment. Chemosphere, 75(6), 788-794 http://dx.doi.org/ 10.1016/j.chemosphere.2008.12.057

Khorshidian, N., Yousefi, M., Hosseini, H., Shadnoush, M., \& Mortazavian, A. M (2016). Potential anticarcinogenic effects of lactic acid bacteria and probiotics in detoxification of process-induced food toxicants. Iranian Journal of Cancer Prevention, 9(5). http://dx.doi.org/ 10.17795/ijcp-7920

Mandal, S. K., \& Das, N. (2018). Enhanced biodegradation of high molecular weight PAHs using yeast consortia immobilized on modified biowaste material. Journal of Microbiology, Biotechnology and Food Sciences, 7(6), 594-601. http://dx.doi.org/10.15414/jmbfs.2018.7.6.594-601

Mocek, K., \& Ciemniak, A. (2016). Influence of physical factors on polycyclic aromatic hydrocarbons (PAHs) content in vegetable oils. Journal of Environmental Science and Health, Part B, 51(2), 96-102. https://doi.org/10.1080/03601234.2015.1092820

Naseri, M., Rezaei, M., Moieni, S., Hosseni, H., \& Eskandari, S. (2010). Effect of different precooking methods on chemical composition and lipid damage of silver carp (Hypophthalmichthys molitrix) muscle. International journal of food science \& technology, 45(10), 1973-1979. https://doi.org/10.1111/j.13652621.2010.02349.x

Niderkorn, V., Boudra, H., \& Morgavi, D. (2006). Binding of Fusarium mycotoxins by fermentative bacteria in vitro. Journal of Applied Microbiology 101(4), 849-856. http://dx.doi.org/10.1111/j.1365-2672.2006.02958.x

Purcaro, G., Moret, S., \& Conte, L. S. (2013). Overview on polycyclic aromatic hydrocarbons: Occurrence, legislation and innovative determination in foods Talanta, 105, 292-305. http://dx.doi.org/10.1016/j.talanta.2012.10.041

Ryu, E. H., \& Chang, H. C. (2013). In vitro study of potentially probiotic lactic acid bacteria strains isolated from kimchi. Annals of microbiology, 63(4), 1387 1395. http://dx.doi.org/10.1007/s13213-013-0599-8

Serrano-Niño, J., Cavazos-Garduño, A., Cantú-Cornelio, F., Gonzalez-Cordova, A., Vallejo-Cordoba, B., Hernández-Mendoza, A., \& García, H. (2015). In vitro reduced availability of aflatoxin $\mathrm{B}_{1}$ and acrylamide by bonding interactions with teichoic acids from Lactobacillus strains. LWT-Food Science and Technology, 64(2), 1334-1341. http://dx.doi.org/10.1016/j.1wt.2015.07.015

Shi, L. K., Zhang, D. D., \& Liu, Y. L. (2016). Incidence and survey of polycyclic aromatic hydrocarbons in edible vegetable oils in China. Food Control, 62, 165 170. http://dx.doi.org/10.1016/j.foodcont.2015.10.037 
Tumbarski, Y., Yanakieva, V., Nikolova, R., Mineva, G., Deseva, I., Mihaylova, D., \& Ivanov, I. (2018). Antifungal effect of a bacteriocin of Bacillus methylotrophicus BM47 and its potential application as a biopreservative in traditional Bulgarian yogurt. Journal of Microbiology, Biotechnology and Food Sciences, 8(1), 659-662. http://dx.doi.org/10.15414/jmbfs.2018.8.1.659-662

Yousefi, M., Khorshidian, N., Mohammad Mortazavian, A., \& Hosseini, H (2017). A review on the impact of herbal extracts and essential oils on viability of probiotics in fermented milks. Current Nutrition \& Food Science, 13(1), 6-15. http://dx.doi.org/10.2174/1573401312666161017143415

Yousefi, M., Khorshidian, N., \& Hosseini, H. (2021). In vitro PAH-binding ability of Lactobacillus brevis TD4. Polycyclic Aromatic Compounds, 1-17. http://dx.doi.org/10.1080/10406638.2021.1889624

Yousefi, M., Shariatifar, N., Tajabadi Ebrahimi, M., Mortazavian, A. M., Mohammadi, A., Khorshidian, N., Arab, M., \& Hosseini, H. (2019). In vitro removal of polycyclic aromatic hydrocarbons by lactic acid bacteria. Journal of Applied Microbiology. https://doi.org/10.1111/jam.14163

Yousefi, M., Shemshadi, G., Khorshidian, N., Ghasemzadeh-Mohammadi, V., Fakhri, Y., Hosseini, H., \& Khaneghah, A. M. (2018). Polycyclic aromatic hydrocarbons (PAHs) content of edible vegetable oils in Iran: A risk assessment study. Food and Chemical Toxicology. http://dx.doi.org/10.1016/j.fct.2018.05.063 Zeledon-Toruno, Z. C., Lao-Luque, C., De Las Heras, F. X. C., \& Sole-Sardans, M. (2007). Removal of PAHs from water using an immature coal (leonardite). Chemosphere, 67(3), 505-512. https://doi.org/10.1016/j.chemosphere.2006.09.047

Zhao, H., Zhou, F., Qi, Y., Dziugan, P., Bai, F., Walczak, P., \& Zhang, B. (2013). Screening of Lactobacillus strains for their ability to bind Benzo (a) pyrene and the mechanism of the process. Food and Chemical Toxicology, 59, 67-71. http://dx.doi.org/10.1016/j.fct.2013.05.040

Zhu, Y.-T., Yang, C.-X., Luo, B.-B., Zhou, K., \& Liu, S.-L. (2017). Efficiency of dairy strains of lactic acid bacteria to bind bisphenol A in phosphate buffer saline. Food Control, 73, 1203-1209. https://doi.org/10.1016/j.foodcont.2016.10.039

Zou, Z., Sun, J., Huang, F., Feng, Z., Li, M., Shi, R., Ding, J., \& Li, H. (2015). In vitro removal of T-2 toxin by yeasts. Journal of Food Safety, 35(4), 544-550. https://doi.org/10.1111/jfs.12204 